\title{
健康成人咽頭好気性菌叢の構成にかんする研究
}

\author{
金沢大学医学部第三内科（主任 服部絢一教授） \\ 舟田久
}

\section{A STUDY ON COMPOSITION OF NORMAL PHARYNGEAL FLORA}

Hisashi Funada, M.D.

The Third Department of Internal Medicine, Kanazawa University, School of Medicine,

Kanazawa, Ishikawa, Japan (Directeor: Prof. Kenichi Hattori)

\begin{abstract}
概要 金沢市在住の満15才〜69才の健康人 167名を対象に，咽頭菌叢の構成について種々の镂点から

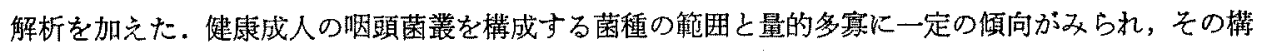
成は，本質的には，性別，年令户乫煙に左右されないものであつた。健康成人の咽頭菌㪨は， $\alpha$-Streptococcus, Neisseria, $\boldsymbol{\gamma}$-Streptococcus, Micrococcus, Corynebacterium 5 菌種による固定的菌叢と, 通常，2〜4種の菌による流動的菌叢からなりたら, 全体としての堅牢性を維持していると考えられ た. 季節的啠動からみると, 冬期に分離菌種の範围や健康人一人あたりの分離菌種数のみならず, 各 菌の倹出率が夏期よりも增大する傾向にあり，さらに，冬期菌叢には，老令や孯煙の影照ならびに菌

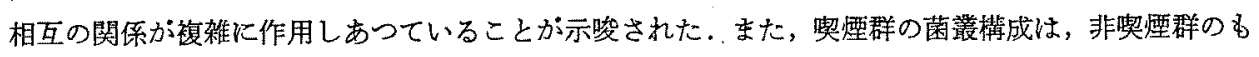

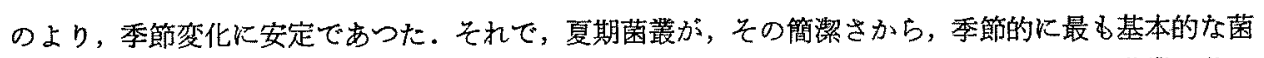

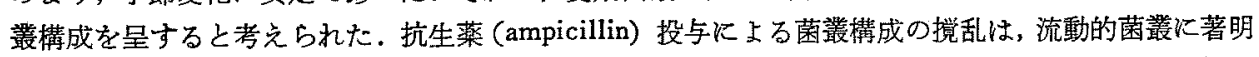
にあらわれ，みかけ上の変化が回復してわ，さらに引き続くことが示された。咽頭にグラム陰性桿菌 を有する健康成人には，生菌や加熱菌に対する血中抗体価の上界を認めなかつた。これらの成績は， 一般呼吸器感染症や宿主防禦能低下時に発症する感染症の原因菌恰索のために実施される咽頭培羡の 成績の解积に有用であることが示唆された。
\end{abstract}

\section{緒言}

咽頭菌叢を構成する菌が豊富なことと個々の菌 に対する臨床細菌学的知識が不充分なことから， 従来の咽頭培盖では，病原性の高い菌のみが注目 され，病原性の低い，いわゆる弱毒菌”は見捨て られる傾向にあつた。しかし，近年，弱毒菌感染 症が増加する゙従つて，これらの菌を再認識す る必要が生じてきた。弱毒菌が宿主防禦能の低下 時に病原性を発揮するにいたる際には, 常在菌蓺 に子なんらかの生態学的変化を伴うことが当然予

〔昭和50年 4 月 4 日受稿]
想される，他方，健康成人の咽頭菌叢について は，各種細菌の検出率の報告は多数あつても ${ }^{3)}$ ， その棈成に言及したすのはほとんどないと言つて よい。

このため，健康成人の咽頭菌叢の構成について の解析は, 一般呼吸器感染症や宿主防禦能の低下 時に発症する感染症において，原因菌検索》ののた めに行なわれる咽頭培湌の成績の解积に極めて有 用な手桬りを与えることになる。

本研究では, 健康成人の咽頭菌叢について, 珄

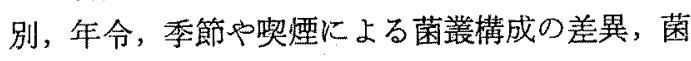
藂の週的変動ならびに抗生薬投与が菌諘に及ぼす 
Table 1. Distribution of healthy subjects.

A) Winter Series (Dec. 1972 - Feb. 1973)

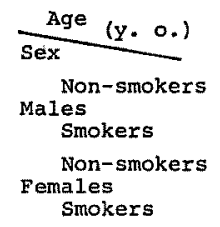

$\begin{array}{cc}15--19 & 20--29 \\ 5 & 10 \\ 0 & 5 \\ 6 & 21 \\ 0 & 1\end{array}$

$30--39 \quad 40$
10
2
10
1

$40-49 \quad 50$
10
4
11
2

\begin{tabular}{rrr}
$50--59$ & $60--69$ & Total \\
10 & 10 & 55 \\
6 & 3 & 20 \\
10 & 11 & 69 \\
1 & 1 & 6 \\
\hline & & 150
\end{tabular}

B) Summer Series (Jun. - Aug. 1973)

\begin{tabular}{|c|c|c|}
\hline sex $(y \cdot 0)$. & $15--19$ & $20--29$ \\
\hline $\begin{array}{l}\text { Non-smokers } \\
\text { Males }\end{array}$ & 1 & 7 \\
\hline Smokers & 0 & 6 \\
\hline $\begin{array}{l}\text { Non-smokers } \\
\text { Females }\end{array}$ & 1 & 7 \\
\hline Smokers & 0 & 0 \\
\hline
\end{tabular}

$30-39$
4
6
10
1

$40--49$
3
4
7
2

$50--59$
5
7
8
0

$$
60--69 \text { Total }
$$

\begin{tabular}{rr}
1 & 21 \\
7 & 30 \\
18 & 51 \\
0 & 3 \\
\hline & $105 *$
\end{tabular}
* : 88 of these subjects (non-smokers: 65 ; smokers: 23 ) were also
examined in the winter series.

影響を検討したので，その成績を報告する。

\section{研究対象}

金沢市在住の満15才から69才までの病歷と理学 的検查所見に異常のない健康成人を対象とした。 過去 2 力月間に抗生薬の服用のないこと, 扁桃摘 出や切除術を受けたことのないこと，歯科的疾患 がなく，義歯でもよいが朄数に欠如のないこと， および過去 2 週間にアルュール類の飲用のないこ とも条件にした。

1）冬期健康成人咽頭菌叢の調否対象

1972年12月から1973年 2 月までの 3 力月間に， 性別，年令と梨煙の偏りをなくすために，男女各 年令につき少なくとも 1 名の非契煙者を含むよう に心眯けた。調査総人数は 150 名で, その内分け は，表1に示した。

なお，青，壮年者層と老年者層の年令境界は， Matsuba $5^{5)}$ 健康人血将蛋白分画の調查結果を 参考にして，60才とした。契煙者とは，1日に紙 巻きタバュを10本以上契筀するるのをさし，非 哭荎者とは，まつたく喫煙しないものをさしてい る。

2）夏期健康成人咽頭菌䔲の調查対象
1973年 6 月から同年 8 月までの 3 カ月間に, 冬 期と夏期の咽頭菌叢の構成の比較のため, 前回の 調查対象者を中心に，それ以外の若干の健康成人 を加えて調査した，表1に示したように，調查総 人数は，105名で, 前回の調查対象者は, そのう ちの83.8\%（88名）を占めた。夏期に新しく調査 対象となつたのは，葜煙男子10名と非梨煙女子 （60〜69才）の7名である。

3）咽頭菌丵の週的変動の調査対象

夏期咽頭菌叢の調査に引き続いて，1973年 9 月 から同年10月までの 2 力月間に，毎週定期的な咽 頭培養が可能な，20４0才台の非知煙健康成人 13 名（男 7 名，女6名）を対象とし，毎週同一日時 に一斉に実施した。

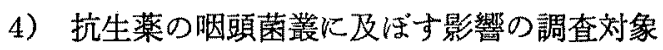
上記週的変動調査と平行して，20才台の非照煙 健康人男子 3 名, 女子 2 名のvolunteerを対象とし た. ampicillin (AB-PC) $2 \mathrm{~g} /$ 日 $(0.5 \mathrm{~g} \times 4)$ の 経口を7日間に行なつて, 抗生薬投与前後の㸶頭 菌對の变動を 2 カ月間にわたり調查した。

\section{研究方法}

a) 咽頭細菌検查法 
Table 2. Isolation media used in this study.
1. Blood agar*
in both aerobic and candle-jar cultures
2. Chocolate agar*
in both aerobic and candle-jar cultures
3. Modified Drigalski agar 'Eiken'
4. MacConkey agar 'Nissan'
5. Sabouraud dextrose agar 'Eiken'
6. Candida GS agar 'Eiken'
7. PEA azide agar 'Eiken'
8. Mannitol salt agar 'Eiken'
9. HB diphtheria agar 'Eiken'
10. Modified Thayer-Martin agar 'Nissan' in candle-jar culture only
11. EF agar 'Nissan'
12. Rogosa agar ${ }^{8}$ ) *: Tryptosoy agar 'Eiken' was supplemented
with 58 sheep red blood cells.

1）検体の採取：検体の採取は，当科研究室 で午前10時頃，水道水によるうがいを充分にさせ たあと，炭末処理滅菌綿棒で他の部位に触れない ように，右側扁桃表面を強くこすつて分泌物をと り，直ちに塗枺検查と培養検査に供した。

2）塗枺検查と培盖検查： 小酒井 ${ }^{6}$ 々 $と$ Cowan \& Steel ${ }^{\text {) }}$ の成書に 従つて, 好気性菌についての み確認培養を行なつた。本研究に使用した分離培 地は表 2 に揭げた。

3）集落の量的表現：咽頭粘液中の細菌数を 定量することは困難なので，各菌種の平板上にお ける集落数を表 3 のごとき 5 段階に分けて記録し た。しかし，検体の採取や平板への塗布の仕方 で，時に分離平板上の集落数が少ないことがある ので，少なくとも一菌種以上が卅を示す培盖成續 が集計に加えられた。なお，一菌種以上が州を示 さない場合には，再検查の5え集計に加えられ た，集落数の観察は，分離培責24時間後之48時間 後の 2 回行なつた。

4）培養成績の集計と処理方法：検出率の有

Table 3. Semi-quantitative estimation of microbial colonies.

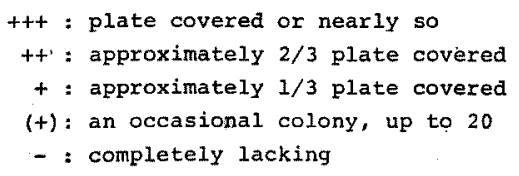

意差検定は, chi square analysiskより，必要に応 じてYatesの修正を加光た。

\section{b) 血中抗体価の測定}

Haemophilus属を除くグラム陰性桿菌 (G N R) の同一菌種が 2 回以上分離された 健康人につい て，生菌と加熱菌に対する血中抗体価の湘定を行 なつた。

冬期と夏期の両咽頭培盖で同一菌種の G N Rが 分離された健康人では，夏期の菌株とその同定時 の血清を使用した。

咽頭菌叢の週的変動調查では，2回以上同一菌 種を分離した健康人について，その最終分離株と 調查開始前血清ならびに最終咽頭培養実施後血清 を使用した。

抗生薬投与剂では，投与後 2 回以上同一菌種が 分離された場合に，その最終分離菌株と投与前血 清ならびに投与終了 2 週後と 6 週後の血清を使用 した.

なお，同一菌種であつても，生物学的性状検査 で 2 性状以上，また，薬物感受性試験で 2 郕以上 の違いを示す菌株は除外した，加熱菌の作製なら びに抗体価の測定は，既報 ${ }^{2)}$ に從つた。

\section{成 績}

\section{1）冬期と夏期の健康成人咽頭菌裳の搆成}

冬期に和ける健康成人 150 名と，夏期に括ける 105名の咽頭培壁で分離された菌種，ならびにそ の検出頻度と百分率を表 4 に示した．冬期には 29 種類，夏期には24種類の菌が分離された．検出率 が60\%近く，あるいは，それ以上の菌種について 办ると，冬期には $\alpha$-Streptococcus, Neisseria, $\gamma$ Streptococcus, Microccus, Staph. aureus, $H$. influenzae, H. parainfluenzae, Corynebacterium, Lactobacillusの 9 種類で夏期は 6 種類で, Staph. aureus, H. influenzae, Lactobacillusの 3 菌種は 検出率が60\%以下に低下した。 また，季節に関係 なく，検出率の高いものは分離平板上でも多数を 占める割合が高いが，検出率の低いものでは， $\beta$-StreptococcusとD. pneumoniaeを除いて，分離 平板上で占める割合が低い傾向がみられた。さら 
Table 4. Composition of pharyngeal flora in healthy subjects.

\begin{tabular}{|c|c|c|c|c|c|c|c|c|c|c|c|c|}
\hline Species or Group & $\begin{array}{r}\text { Wi } \\
\text { Dist } \\
+++ \\
\end{array}$ & $\begin{array}{c}\text { ter } \\
\text { ibuti } \\
++ \\
\end{array}$ & $\begin{array}{l}\text { of } \\
+ \\
\end{array}$ & $\begin{array}{l}150 \text { sul } \\
1(+)\end{array}$ & jects & $\begin{array}{l}\text { Total of } \\
\text { Positives }\end{array}$ & $\begin{array}{l}\text { Dist } \\
+++\end{array}$ & $\begin{array}{c}\text { buti } \\
++ \\
\end{array}$ & $\begin{array}{l}n \text { of } \\
+ \\
\end{array}$ & $\begin{array}{c}105 \mathrm{Su} \\
(+)\end{array}$ & $\begin{array}{c}\text { bjects } \\
-\end{array}$ & $\begin{array}{l}\text { Total of } \\
\text { Positives }\end{array}$ \\
\hline $\begin{array}{l}\alpha \text {-Streptococcus } \\
\text { Neisseria } \\
\gamma \text {-Streptococcus } \\
\text { Micrococcus } \\
\text { Staph. aureus } \\
\text { Staph. epidermidis } \\
\text { H. influenzae } \\
\text { H. parainfluenzae } \\
\text { H. haemolyticus } \\
\text { H. parahaemolyticus } \\
\text { H. haemoglobinophilus } \\
\text { Corynebacterium } \\
\text { Klebsiella } \\
\text { Enterobacter } \\
\text { E. coli } \\
\text { Pseudomonas } \\
\text { A. anitratus } \\
\text { Moraxella } \\
\text { C. albicans } \\
\text { Other Candidas } \\
\text { Lactobacillus** } \\
\text { Group A B-Streptococcus } \\
\text { Non-group A,D } \\
\text { B-Streptococcus } \\
\text { D. pneumoniae } \\
\text { Aerococcus } \\
\text { B. subtilis } \\
\text { B. cereus } \\
\text { B. pulvifaciens } \\
\text { Actinomyces }\end{array}$ & $\begin{array}{r}150 \\
119 \\
56 \\
53 \\
11 \\
1 \\
22 \\
55 \\
2 \\
20\end{array}$ & $\begin{array}{r}28 \\
56 \\
59 \\
23 \\
1 \\
42 \\
53 \\
\\
22 \\
57\end{array}$ & $\begin{array}{r}3 \\
34 \\
26 \\
25 \\
5 \\
24 \\
16 \\
2 \\
18 \\
1 \\
52 \\
1\end{array}$ & $\begin{array}{r}1 \\
6 \\
28 \\
28 \\
6 \\
2 \\
1 \\
2 \\
\\
11 \\
8 \\
1 \\
4 \\
1 \\
1 \\
\\
13 \\
9 \\
14 \\
6\end{array}$ & $\begin{array}{r}3 \\
6 \\
63 \\
115 \\
56 \\
24 \\
145 \\
88 \\
149 \\
8 \\
141 \\
149 \\
146 \\
149 \\
149 \\
149 \\
134 \\
136 \\
15 \\
133\end{array}$ & $\begin{array}{r}150(100))^{*} \\
150(100) \\
147(98.0) \\
144(96.0) \\
87(58.0) \\
35(23.4) \\
94(62.7) \\
126(84.0) \\
5(3.3) \\
62(41.3) \\
1(0.7) \\
142(94.7) \\
9(6.0) \\
1(0.7) \\
4(2.7) \\
1(0.7) \\
1(0.7) \\
1(0.7) \\
16(10.7) \\
14(9.3) \\
27(59.5) \\
17(11.4)\end{array}$ & $\begin{array}{r}105 \\
76 \\
53 \\
27 \\
6 \\
1 \\
6 \\
22 \\
\\
3\end{array}$ & $\begin{array}{r}25 \\
26 \\
32 \\
9 \\
1 \\
17 \\
32\end{array}$ & $\begin{array}{r}4 \\
26 \\
30 \\
11 \\
4 \\
10 \\
15 \\
12 \\
33 \\
6 \\
2 \\
2 \\
5 \\
5 \\
15\end{array}$ & $\begin{array}{r}1 \\
2 \\
9 \\
3 \\
2 \\
1 \\
1 \\
1 \\
10 \\
10 \\
27 \\
2\end{array}$ & $\begin{array}{r}14 \\
62 \\
80 \\
72 \\
34 \\
105 \\
77 \\
105 \\
10 \\
90 \\
102 \\
101 \\
104 \\
102 \\
105 \\
90 \\
92 \\
58 \\
102\end{array}$ & 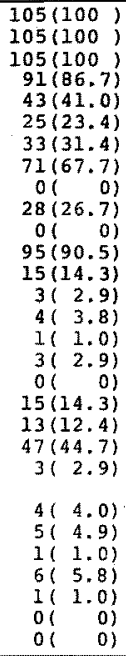 \\
\hline
\end{tabular}

* : Figures in parentheses denote incidence in percent.

** : In the winter series Lactobacillus was examined in only 42 healthy subjects.

Table 5. No. of species and groups composing pharyngeal fiora in each of healthy subjects.

\begin{tabular}{|c|c|c|c|c|c|c|c|c|c|c|}
\hline $\begin{array}{c}\text { No. of Species } \\
\text { and Groups* }\end{array}$ & 4 & 5 & 6 & 7 & 8 & 9 & 10 & 11 & 12 & Total \\
\hline Winter Series & & & $13 * \star$ & 26 & 50 & 37 & 15 & 8 & 1 & 150 \\
\hline Summer Series & 1 & 9 & 19 & 24 & 31 & 15 & 5 & 1 & & 105 \\
\hline
\end{tabular}

* : Lactobacillus was excluded from this investigation.

** : no. of healthy subjects

に，各genusに含まれる菌種間の検出率の高低の 順序には，李節に関係なく，一定の傾向がみられ た. Staphylococcus属では, Staph. aureus, Staph. epidermidisの順で検出率方高く， Staph. epidermidisの検出率は，冬期と夏期に战いて 同率であ つた. Haemophilus属では，H. parainfluenzae, H. influenzae, H. parahaemolyticus の順であつ た. Haemophilus䳽を除く G N Rでは, Klebsiella, 次いでE. coliの検出率が高かつた。Candidaでは， C. albicansが他のcandidaに比して梌出率が高か つた．Bacillus属では，B. subtilisの検出率が一番 高からな。

咽頭菌罣を構成する菌種数を各健救人について
調查し，その集計を季節別に表 5 に示した。冬期 には，健康人につき 6 亿種類の菌が見い出さ れ，8〜9種類の頻度が高かつた. 一方, 夏期に は, 健康人につき $4 \sim 11$ 種類の菌范見い出され， $7 \sim 8$ 種類の頻度が高かつた。つまり，冬期に比 して，夏期には各健康人から分離される菌種数が 減少する傾向が窥われた。

なお゙，冬期でも夏期でも健康人一人あたりから 分離された菌種数には，性別，年令や喫煙による 差異は認められず，夏期には，冬期に比べて，一 様の減少を示す傾向にあらた。

菌相互の関係について調查した成績を表 6 に示 した。冬期と夏期ともに，Staph. aureus と Staph. 
Table 6. Microbial interactions in composition of pharyngeal flora.

(A)

\begin{tabular}{|c|c|c|}
\hline other Organism & $\begin{array}{c}\text { Swabs with } \\
\text { Present }\end{array}$ & $\begin{array}{l}\text { - aureus } \\
\text { Absent }\end{array}$ \\
\hline $\begin{array}{l}\text { staph. epider- } \\
\text { midis Present }\end{array}$ & ${ }^{7} / 1{ }^{*}$ & $\stackrel{28}{/ 24}$ \\
\hline $\begin{array}{c}\text { Staph. epider- } \\
\text { midis Absent }\end{array}$ & ${ }^{80} / 42$ & $35 / 38$ \\
\hline
\end{tabular}

Winter Series: $x^{2}=27.06147 \quad(p<0.001)$

Summer series: $x^{2}=18.52860 \quad(p<0.001)$

(B)

\begin{tabular}{c|c|c|} 
Other Organism & \multicolumn{2}{|c|}{$\begin{array}{c}\text { Swabs with Lactobacillus } \\
\text { Present }\end{array}$} \\
\hline $\begin{array}{c}\text { Candida } \\
\text { Present }\end{array}$ & $11 / 18$ & $1 / 10$ \\
\hline $\begin{array}{c}\text { Candida } \\
\text { Absent }\end{array}$ & $16 / 29$ & 14 \\
\hline \multicolumn{2}{|c|}{ Winter Series: $x^{2}=3.94333$} & $(p<0.05)$ \\
Summer Series: $x^{2}=5.88625$ & $(p<0.05)$
\end{tabular}

* : no. of swabs encountered in the winter series no. of swabs encountered in the summer series

epidermidisの間に干渉の関保が，Candida と Lactobacillusの間に共存の関係がみられた。

\section{2）健康成人咽頭菌叢の季節内と季節間比較}

冬期と夏期の咽頭菌對の構成について, 性別, 年 令や契煙による差異を椧討したのが表 7ーAであ る. 冬期咽頭菌對の構成には, 非喫煙群で性別に 上る有意の差をみないが，年令に上る有意の差が Staph. epidermidisとCandida認められ，両者之 も老年者層に検出率が高かつた。喫煙の有無によ る有意の差は，Staph. aureus々Staph. epidermidis に認められ, 前者は非照煙群, 後者は喫煙群に検 出率が高かつた。恐らく，冬期に，老令と盁煙の 因子がStaph. epidermidisの咽頭への定着を助長 するように思われた。一方, 夏期咽頭菌對の構成 には，非契煙群で性別，年命による有意差はな く，また奥煙による有意の盖は認められなかつ た，上述の夏に叔ける健康成人の咽頭培着で分離 された菌種数や健康人一人むたりの菌對構成菌種 数の成續とあわせて，健康成人の夏期咽頭菌䔖 は，性別，年令や契煙の因子に左右されない最も 基本的な構成を呈すると考えられる。

冬期と夏期の㸶頭菌叢の梢成について，季節間

Table 7. Difference in composition of pharyngeal flora.

(A) Intraseasonal Difference

a) Winter series $(\mathrm{N}=150)$

1) Sex Difference (Non-smokers)

Males: $n=55$, Females: $n=69$

No significant difference

2) Age Difference (Non-smokers)

$\left.\begin{array}{l|c|c}\text { Organism } & \begin{array}{c}\text { Adult } \\ \mathrm{n}=103\end{array} & \begin{array}{c}\text { Aged } \\ \mathrm{n}=21\end{array} \\ \hline \begin{array}{l}\text { Staph. } \\ \text { epidermidis }\end{array} & 16^{*} & 9 \\ \hline \text { Candida } & 18 & 9\end{array}\right\} \begin{gathered}0 \\ 0\end{gathered}$

3) Difference Related to Smoking

$\left.\begin{array}{l|c|c}\text { Organism } & \begin{array}{c}\text { Non-smoker } \\ n=124\end{array} & \begin{array}{c}\text { Smoker } \\ n=26\end{array} \\ \hline \text { Staph. aureus } & 79 & 8 \\ \hline \begin{array}{c}\text { Staph. } \\ \text { epidermidis }\end{array} & 25 & 10\end{array}\right\} \begin{gathered}0 \\ 0_{4}\end{gathered}$

(B) Interseasonal Difference

1) Non-smokex Groups

\begin{tabular}{l|c|c} 
Organism & $\begin{array}{c}\text { Winter } \\
\mathrm{n}=124\end{array}$ & $\begin{array}{c}\text { Sumner } \\
\mathrm{n}=72\end{array}$ \\
\hline Micrococcus & 119 & 61 \\
\hline Staph. aureus & 79 & 26 \\
\hline $\begin{array}{c}\text { H. influenzae } \\
\text { H. para- } \\
\text { influenzae }\end{array}$ & 74 & 21 \\
\hline Klebsiella & 106 & 48 \\
\hline
\end{tabular}

b) Sumner Series $(\mathrm{N}=105)$

1) Sex Difference (Non-smokers)

Males: $n=21$, Females: $n=51$

No significant difference

2) Age Difference (Non-smokers)

Adult: $n=53$, Aged: $n=19$

No significant difference

3) Difference Related to Smoking Non-smokers: $n=72$, Smokers: $n=33$

No significant difference

2) Smoker Groups

\begin{tabular}{l|c|c} 
Organism & $\begin{array}{c}\text { Winter } \\
\mathrm{n}=26\end{array}$ & $\begin{array}{c}\text { Summer } \\
\mathrm{n}=\mathbf{3 3}\end{array}$ \\
\hline H. influenzae & 20 & $\mathbf{2 0}$ \\
\hline & $\mathrm{p}<0.05$
\end{tabular}

* : no. of positive subjects 
Table 8. Seasonal variation in haemophilus species.

\begin{tabular}{|c|c|c|c|}
\hline $\begin{array}{l}\text { No, of } \\
\text { Species }\end{array}$ & Combination & Winter & Summer \\
\hline 1 & $\begin{array}{l}\text { H. inf. only } \\
\text { H. parainf. only } \\
\text { H. haemo, only } \\
\text { H. parahaeno. only }\end{array}$ & $\begin{array}{c}9 * \\
20 \\
1 \\
6\end{array}$ & $\begin{array}{r}6 \\
36 \\
0 \\
9\end{array}$ \\
\hline & \begin{tabular}{|c|c|} 
sum \\
\end{tabular} & 36 & 51 \\
\hline 2 & $\begin{array}{l}\text { H. inf. H. parainf. } \\
\text { H. inf. \& H. haemo. } \\
\text { H. inf. H. parahaemo. } \\
\text { H. parainf. H. parahaemo. } \\
\text { H. haemo. H. parahaemo. }\end{array}$ & $\begin{array}{r}51 \\
1 \\
1 \\
23 \\
1\end{array}$ & $\begin{array}{r}18 \\
0 \\
2 \\
10 \\
0\end{array}$ \\
\hline \multirow[b]{2}{*}{3} & \begin{tabular}{|l|l|} 
& sum \\
\end{tabular} & 77 & 30 \\
\hline & $\begin{array}{l}\text { F. inf., H. parainf. } \\
\text { \& H. haemo. } \\
\text { H. inf., H. paraine. } \\
\text { H. parahaemo. }\end{array}$ & $\begin{array}{r}1 \\
29\end{array}$ & $\begin{array}{l}0 \\
7\end{array}$ \\
\hline & \begin{tabular}{|l|l|} 
& sum \\
\end{tabular} & 30 & 7 \\
\hline \multirow[t]{2}{*}{4} & $\begin{array}{l}\text { H.inf., H. parainf., } \\
\text { H. haemo. \& H. parahaemo. } \\
\text { H. inf., H. parainf., } \\
\text { H. parahaemo. \& H. haemogl. }\end{array}$ & $\begin{array}{l}1 \\
1\end{array}$ & 0 \\
\hline & \begin{tabular}{|l|l} 
& sum \\
\end{tabular} & 2 & 0 \\
\hline \multirow[t]{2}{*}{0} & Negative & 5 & 17 \\
\hline & Total & 250 & 105 \\
\hline
\end{tabular}

差異を検討したのが表7-Bである。非契垔群で は, Micrococcus, Staph. aureus, H. influenzae,
H. parainfluenzae, Klebsiellaの 検出率に 有意の 差がみられ，Klebsiellaを除く他の 4 菌種は，夏 期に検出率の減少を示した。鿄煙群では，H． influenzaeの検出率だけが夏期に有意の減少を示し た．季節間差異の検討で有意の差を示した菌種数

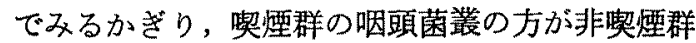
のものより季節变化に安定であると考兄られた.

同一genusの菌種の組み合わせに批㺭る季節変 化をHaemophilus属で検討したのが表8である.

組み合わせの菌種数について，冬期は 2 菌種での 頻度が高いのに比して，夏期は 1 菌種での頻度が 高かつた，組み合わせの種類でみると，冬期と夏 期ともに, 1 菌種単独のものでは, H. parainfluenzae, 2 菌種のものではH. influenzae とH. parainfluenzaeの組文合わせ， 3 菌種のるのでは，H. influenzae, $H$. parainfluenzae $\prec H$. parahaemolyticusの組み合わせの頻度が高かつた４菌種の組 み合わせは，冬期にみられたのみであつた。全

Table 9. Weekly throat cultures in 13 healthy subjects*.

\begin{tabular}{|c|c|c|c|c|c|c|c|c|c|}
\hline $\begin{array}{l}\text { Details in } \\
\text { Positive subjects } \\
\text { Species or cultures } \\
\text { or Group }\end{array}$ & $\begin{array}{l}\text { No. of } \\
\text { Positive } \\
\text { Subjects } \\
\text { (A) } \mathrm{N}=13\end{array}$ & $\begin{array}{l}\text { No. of } \\
\text { Positive } \\
\text { Cultures } \\
N=104\end{array}$ & $\begin{array}{l}\text { Dist } \\
\text { Posi } \\
+++\end{array}$ & $\begin{array}{l}\text { ribu } \\
\text { tive } \\
++\end{array}$ & $\begin{array}{c}\text { tion } \\
\text { cu } \\
+\end{array}$ & $\begin{array}{l}\text { of } \\
\text { tures } \\
(+)\end{array}$ & $\begin{array}{l}\text { No. of Po } \\
\text { Cultures } \\
\text { Positive } \\
\text { Median }\end{array}$ & $\begin{array}{l}\text { sitive } \\
\text { per } \\
\text { Subject } \\
\text { Range }\end{array}$ & $\begin{array}{l}\text { No. of Positive } \\
\text { Subjects with } \leqq 3 \\
\text { Positive Cultures } \\
\text { (B) }\end{array}$ \\
\hline$\alpha$-streptococcus & 13 & 104 & 104 & & & & 8 & 8 & (2) \\
\hline Neisseria & 13 & 104 & 87 & 17 & & & 8 & 8 & - \\
\hline$\gamma$-streptococcus & 13 & 103 & 54 & 28 & 21 & & 8 & $7-8$ & - \\
\hline Micrococcus & 13 & 98 & 31. & 33 & 32 & 2 & 8 & $7-8$ & $\ldots$ \\
\hline Staph. aureus & 12 & 84 & 6 & 14 & 42 & 22 & 8 & $3-8$ & $1\left(88^{* *}\right)$ \\
\hline staph. epiaermidis & 6 & 15 & & & 4 & 11 & 1.5 & $1-6$ & $4(678)$ \\
\hline H. influenzae & 10 & 33 & 4 & 17 & 9 & 3 & 3 & $2-5$ & $6(608)$ \\
\hline H. parainfluenzae & 13 & 85 & 21 & 38 & 25 & 1 & 7 & $4-8$ & $\longrightarrow$ \\
\hline 4. parahaemolyticus & 13 & 43 & & 22 & 15 & 6 & 3 & $1-6$ & $7(548)$ \\
\hline Corynebactexium & 13 & 96 & 12 & 34 & 47 & 3 & 8 & $6-8$ & $\longrightarrow$ \\
\hline Klebsiella & 7 & 12 & & & 2 & 10 & 2 & $1-3$ & $7(1008)$ \\
\hline Enterobacter & 5 & 9 & & 1 & 2 & 6 & 1 & $1-4$ & $4(808)$ \\
\hline E. $\operatorname{col} i$ & 3 & 3 & & 1 & & 2 & 1 & 1 & $3(1008)$ \\
\hline Moraxella & 1 & 1 & & & 1 & & 1 & 1 & $1(1008)$ \\
\hline Candida & 7 & 21 & 1 & & 4 & 16 & 4 & $1-5$ & $3(438)$ \\
\hline Lactobacillus & 12 & 26 & & & 6 & 20 & 2 & $1-6$ & $11(928)$ \\
\hline Group A B-streptococcus & 1 & 1. & & & & 1 & 1 & 1 & $1(1008)$ \\
\hline $\begin{array}{r}\text { Non-group } A, D \\
\beta-S \text { treptococcus } \\
\end{array}$ & 5 & 8 & 2 & 2 & 3 & 1 & 1 & $1-3$ & $5(1008)$ \\
\hline D. pneumoniae & 4 & 7 & 1 & 2 & 3 & 1 & 1.5 & $1-3$ & $4(1008)$ \\
\hline Enterococcus & 1 & 1 & & & 1 & & 1 & 1 & $1(1008)$ \\
\hline Aerococcus & 1 & 1 & & 1 & & & 1 & 1 & $1(1008)$ \\
\hline B. subtilis & 2 & 3 & & & & 3 & 1.5 & $1-2$ & $2(1008)$ \\
\hline B. cereus & 2 & 2 & & 1 & & 1 & 1 & 1 & $2(1008)$ \\
\hline
\end{tabular}


般的に，Haemophilus属では，菌種の組み合わせ に季節変化をみないが，夏期は冬期に比べて組み 合わせに含まれる菌種数が減少する傾向がみられ た。

\section{3）健康成人咽頭菌㦪の週的変動}

13名の健康成人に 2 カ月間にわたり，毎週定期 的に一斉に咽頭培養を行なつた成䋶を表 9 に示し た. 分離された菌種総数は23種類であつた。すべ ての健康人に少なくとも 1 回以上検出されたのは 7 菌種で，そのらら少なくとも6 回以上検出され たのは, $\alpha$-Streptococcus, Neisseria, $\gamma$-Streptococcus, Micrococcus, Corynebacteriumの 5 菌種であ つた. 恐らく、この 5 菌種が咽頭菌丵のなかにめ つて固定的なるのと考えられる. H. parainfluenzaeは，すべての健康人より分離され，その分 離回数が $4 \sim 8$ 回, 中央值 7 回との成績から, 咽 頭への定着性は強いものの, 上記グループほど固 定的でなさそうである，その他の菌種は，ぬつた く検出されない健康人があつたり，検出されてる その頻度が健康人により変動が著しかつた。この グループに属する菌種のうちでも, Staph. aureus は，12名の検出者のうちで検出回数が 3 回以下の 人が占める割合は，8\%（1名）にすぎず，ま た，検出者での検出回数の中央値が 8 回であつた ことより，一旦，咽頭に定着すると，その定着性 は堅固なるのであることが示唆された。一方，こ れら 7 菌種を除く 16 菌種は，検出者総数の中で㭘 出回数が 3 回以下の人の占める割合か $43 \sim 100 \%$ であり，また，検出回数の範囲やその中央值よ り,これらの菌は, transient bacteriaの性格が強 いことが想定された。

さらに，健康成人咽頭菌叢の堅牢性を構成菌種 数から検討したのが図 1 と2である。図1は，毎 週咽頭培養実施の都度, 各健康人から分離された 菌種数の中央值を求め，々の週的変動をみたもの である. 1 週目と 2 週目の 9 菌種を除けば，以後 すべて 8 菌種であり，菌種数からみた咽頭菌灇は まつたく堅固と言える．図2は，各健康人あたり 8 回の咽頭培養で分離された菌種数の中央值の度

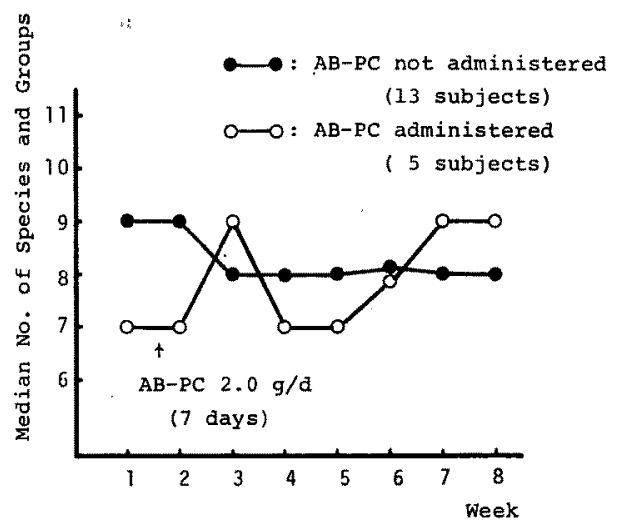

Fig. 1. Stable composition of pharyngeal flora and its derangement due to AB-PC administration.

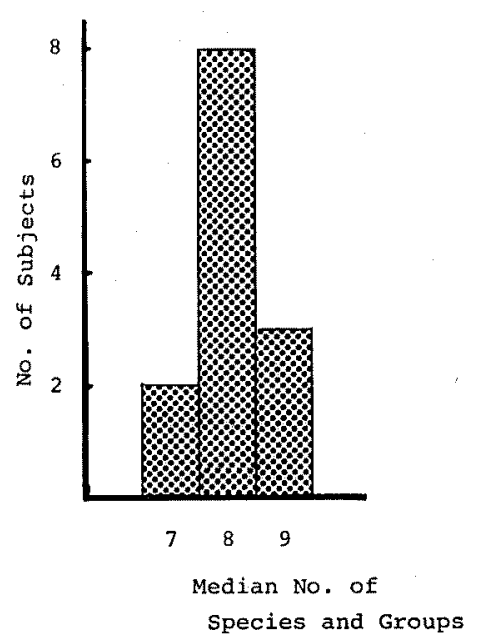

Fig. 2. Uniform composition of pharyngeal flora.

数分布を示したものである．各健康人の中央值の 範囲は $7 \sim 9$ 菌種と狭く, 8 菌種にピークがみら れた。つまり，この調查期間内では, 咽頭菌叢は 上述の 5 菌種を固定的菌丵として，2〜4菌種が 流動的に出入りしたと考兄られた。

4）AB-PC投与が咽頭菌叢の構成に及ぼす影響 上述の週的変動調查之平行して，5名の健康成 人を対象に検討した。図 1 亿非投与群の場合と同 様に，分離菌種数について毎週の中央値をブロッ トして，AB-PC投与後の週的変動をみた。投与群 総数が少なく，詳細な比較は困難であるが，非投 
Table 10. Effect of AB-PC administration on composition of pharyngeal flora.* Comparison of pre-administration flora with post-administration ones.

Dis appearance

Aftex Cessation of AB-PC Administration

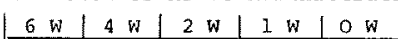

Appearance

After Cessation of AB-PC Administration

\begin{tabular}{|c|c|c|c|c|c|c|c|c|c|c|}
\hline $6 w$ & $4 W$ & $2 w$ & $1 \mathrm{~W}$ & $\mathrm{OW}$ & Organism & $\| \circ \mathrm{W}$ & $1 w$ & $2 w$ & $4 W$ & $6 \mathrm{~W}$ \\
\hline & & & & $3^{* *}$ & $\gamma$-streptococcus & & & & & \\
\hline & & & & 4 & Micrococcus & & & & & \\
\hline & & & & 1 & staph. aureus & & & & & \\
\hline & & & & & Staph. epidermidis & 2 & & & 1 & \\
\hline & & & & & H. influenzae & & 1 & 2 & 2 & 3 \\
\hline & & & & & 1. parainfluenzae & & 1 & 1 & 1 & 1 \\
\hline & & & & & H. haemolyticus & & & & & 1 \\
\hline \multirow[t]{9}{*}{1} & 1 & 1 & 1 & $1^{* \star \star}$ & H. parahaemolyticus & 1 & 1 & & 2 & 1 \\
\hline & & & & 1 & Corynebacterium & & & & & \\
\hline & & & 1 & & Klebsiella & & & & & \\
\hline & & & & & Enterobacter & 3 & 3 & 1 & & \\
\hline & & & & & Serratia & 1 & 1 & & & \\
\hline & & & & & A. anitratus & 1 & & & & \\
\hline & & 1 & & & Candida & 1 & 1 & 2 & 1 & \\
\hline & & & & & Lactobacillus & 1 & 2 & 1 & 2 & 3 \\
\hline & & & & & $\begin{array}{l}\text { Non-group A, D } \\
\beta \text {-streptococcus }\end{array}$ & & & & 1 & 1 \\
\hline \multirow[t]{2}{*}{1} & 1 & 1 & 1 & $1^{\star \star \star}$ & D. pneumoniae & & & & & \\
\hline & & & & & Enterococcus & 1 & & & & \\
\hline
\end{tabular}

* : $\mathrm{AB}-\mathrm{PC}$ in a daily dose of $2.0 \mathrm{~g}(0.5 \mathrm{~g} \times 4$ per os) was administered for 7 days to each of 5 healthy subjects. $\alpha$-streptococcus and Neisseria remained almost unaffected throughout the period of this investigation.

** : no. of healthy subjects

***: Each of these organisins disappeared completely after cessation of AB-PC administration in 2 discrete subjects.

与群に比べ，かなりの変動がみられた. 投与終了 時に菌種数の上での変化はなかつた。しかし，投 与終了後 2 週目に 9 菌種之投与前に比べて 2 菌種 の増加を認め，一旦回復するが，投与終了 6 週以 後再度上昇がみられた。この変化を各菌種別に みたのが表10である， $\alpha$-StreptococcusとNeisseria は，調查全期間を通して常に検出された．投与終 了時にはグラム陽性球菌（G P C）が消失し， G NRが出現するのが特徽であつた。しかし，G PCでも，Staph. epidermidisは逆に出現してい る.しかし，菌種数の出納では差がなかった。 の後週を経るごとに, Haemophilus, Candida, ゃ Lactobacillusは增加し，投与終了時に出現した G N Rは消失している。つまり，抗生薬投与後の菌 叢は，投与終了後 2 週目にみかけ上の変化が回復 するよらにみえるが，上述の非投与群の 2 力月間 の調查結果と比較して，その変化は少なくとも投 与終了後 6 週間以上続くと考えられた。

5） Haemophilus属を除くGNRに対する血中

\section{抗体価の测定}

冬期と夏期に同一G N Rを分離した健康人は 3 名で, 内訳は，Klebsiella 2 名, Enterobacter 1 名 であつた．週的変動調查で 2 回以上同一G N Rを 分離した健康人は 6 名で，内訳は，Klebsiella 3 名, Enterobacter 3 名であつた.さらに，抗生薬投 与後出現 Lた G N Rに対する血中抗体価測定の対 象者は3名で，内訳は，Klebsiella 1 名，Enterobacter 2 名, Serratia 1 名であつた. Klebsiellaて の健康人は投与前上り咽頭に本菌を認めた。 た，他の 1 名は, EnterobacterとSerratiaの同時出 現を認めた。しかし，これらの健康人には，生菌 や加熱菌に対する血中抗体価の上昇を認めたもの がなかつた。

\section{考察}

咽頭培盖は, 呼吸器感染症の原因菌検索のため に行なわれるのが常であるが，近年，急性白血病 などの全身性疾患に合併する感染症は，病初に発 熱老除いて典型的な症状や所見を欠き，感染病晕 
の不明なことが多いので, 咽頭培養がroutine surveillance cultures $\sigma 一$ 環として行われている。 し かし, 宿主防禦能低下時に発症する呼吸器感染症 のみならず，他の感染症の原因菌は，従来の病原 菌に比べて, いわゆる弱毒菌が多いため, 咽頭培 槩で検索する原因菌の範囲が拡大し，培養成績の 解釈に困惑することが多くなつてきた．

また，この弱毒菌と称される菌の多くが，生体 の皮膚や粘膜にみいだされる．咽頭菌叢はあくま でも宿主との関連に拉いてできあがるものである から，当然，宿主からの規制を受ける。それで， 弱毒菌が宿主防禦能低下時に病原性を発揮するに いたる際には, 常在菌叢にもなんらかの生態学的 変化を伴うことが予想される。

この意味で, 健康成人の咽頭にみられる各種細 菌の検出率だけでなく，咽頭菌叢の構成に解析を 加兄ることが，一般呼吸器感染症や宿主防禦能低 下時に発症する感染症の原因菌の予測や決定のた めに行なわれる咽頭培養の成績の解釈に重要な手 懸りを与えてくれることになる。

本研究では, 繁雑さを避けるために, 嫌気性菌 には言及せず，好気性菌のみを対象として，健康 成人の咽頭菌鋠の構成を種々の観点から眺めてみ た．咽頭には，腸管内と同様に嫌気性菌の方が好 気性菌よるもはるかに多数存在しているふので， ここで述べる咽頭菌叢は菌叢の全貌ではなく，そ の一部にすぎない。

培養に際して，図 3 に示したよらな菌相互の干 渉がみられることがあるかもしれない。ある菌が 他に排除あるいは増殖抑制といつた作用を及ぼし たり，Proteus群のように遊走して平板所見を読み とることが不可能なこともおこりらる．それで本 研究では分離培地の種類を増すことにより，でき るた゚け咽頭における好気性菌の全貌を知るように 努めた。

健康成人の咽頭菌叢を構成する菌種には，好気 性菌すべてが菌叢の構成に与かるものではなく， 多少の季節的差異はあつても一定の範囲があり， 菌叢を構成する菌種の多寡にも一定の傾向がみら

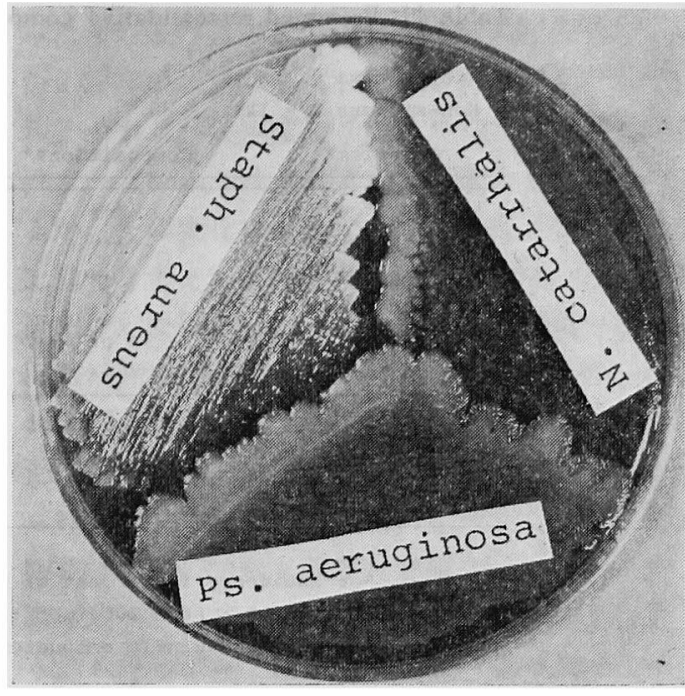

Fig. 3. Inhibition of growth of Staph. aureus and N. catarrhalis by Ps. aeruginosa. All of these strains presented above were isolated from the same throat culture on a patient with acute leukemia.

れた.このことは, Rosebury ${ }^{3)}$ が多数の 研究者の 成績を調査した結果からも窅い知ることができ る.従来より咽頭培羵が対象としてきた $\beta$-Streptococcus, D. pneumoniae, C. diphtheriaepN. meningitidisは健康人に全く検出されないか，検出さ れてもその割合は低かつた。さらに，検出された $\beta$-Streptococcus, D. pneumoniaeでは, 分離平板で 占める割合が他の菌でみられた検出率が低いと分 離平板上でも数少ないといら傾向は認められなか つた。これら 2 菌種は病原性の確立された菌でも あり，健康人に認められた場合には注目を要する かも知れない。

健康人の咽頭菌叢の棈成には，少なからす゚季節 的変動が認められたが，本質的には性別，年令や 契煙による差異はなかつた。健康成人咽頭菌丵 は，夏期に性別，年令や契煙による差異が認めら れず, 分離された菌種総数や一人あたりの健康人 から分離された菌種数の上でも冬期に比べて多少 とも簡潔になつている，それで，季節的には，夏 期咽頭菌叢が最も基本的な様相を呈すると思われ る. 表11に冬期と夏期に高頻度に分離される菌に 
Table 11. Presumed representative composition of pharyngeal flora in healthy subjects.

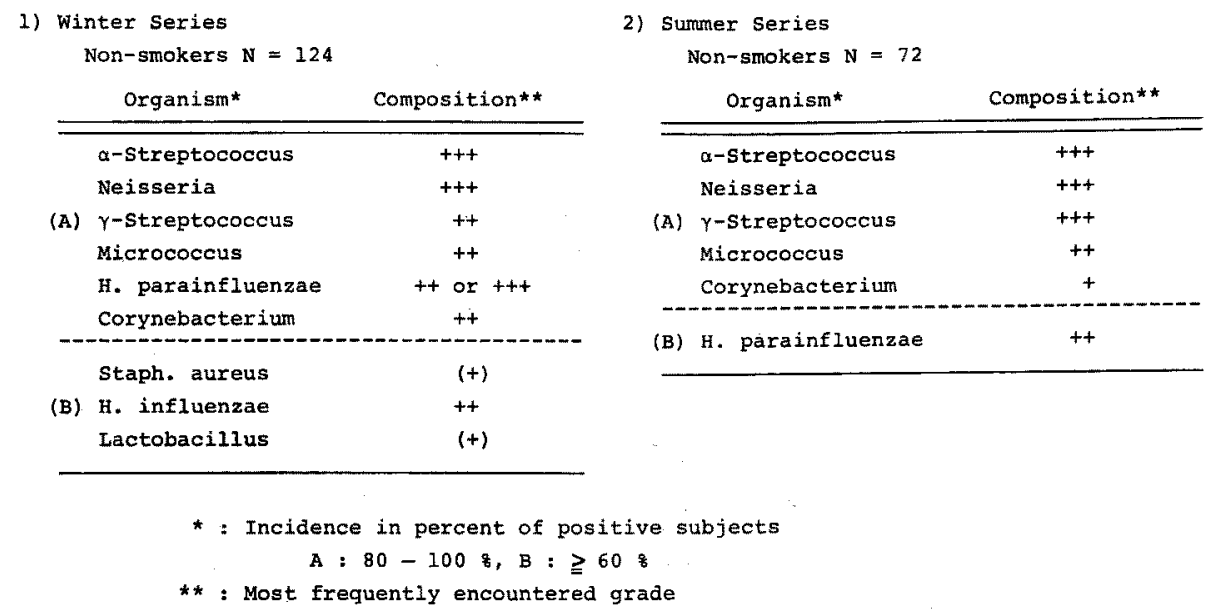

ついて，その分離平板上で最もよくみられる量的 割合を示した，両時期における代表的菌丵とも考 えてょいであるう。

夏期菌叢は,性別,年令や契煙による差異が認め られなかつたのに比して，冬期菌蒦は，老令化や 契塺によりStaph. epidermidisの検出率が高まる傾 向を示した.しかし、これは, Staph. epidermidisの 検出率に冬期と夏期とで变化がみられないのに， Staph. aureusの検出率が冬期に高かつたために，

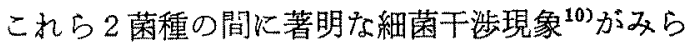
れたにすぎないとも考兄られた。冬期の非契煙群 の年令的差異では, これら2菌種のらちStaph. epidermidisにのみ娭出率に有意の差がみられたが， Staph. aureusは，検出率比校で青，壮年層に高か つた。また，契煙の有無による美巽で，これら2 菌種の開に著明な干涉現像が觀察された。それ

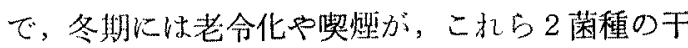
涉の際，Staph，epidrmidisの定着を有利に導く因 子と考允られた。老令層の槃煙者でこのことを検 討すれば，さらに明確になるはずであるが，対象 となる人数が少ないだ確認することがでさなか つた。また，菌相互の関係については，LactobacillusとCandidaの間に共存の関係が みられた。

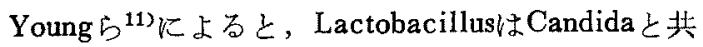

存することにより発育が促進されるが，その結果 生ずる乳酸は，反対にCandidaの 発㕕を阻止する と述べている。

非契煙群で, 冬期と夏期とも火見い出された菌 種においても，その検出率に季節的に有意の差の 認められたものが 5 菌種あつた。そのうちの4 菌 種は夏期に検出率の減少を示したが，Klebsiella のみが夏期に検出率の上昇をみた。 Haemophilus 属の減少がStaph. aureusの減少に伴つてみられ た. Haemophilus属の衛星現象は, 血液平板上で各 種細菌の 集落周囲に 観察されるが，Staphylococcus属の場合に著明にみられるので，雨菌属の菌 が検出率の上で同じ動態を呈するかのようにみ兄 るとはいえ, 本研究での培養成績の推計学的処理 から有意の関係を見い出し党なかつた。をた，夏 期におけるKlebsiellaの検出率の上昇は，夏期に 茵對が簢潔になるため，菌相互の間の関係も複雑 さが除かれ，少数存在していて榆出されやすくな るのではないかとも考えられる。

本質的には，性別，年令，奥厘といつた因子の 影響を受けないと考兄られる咽頭菌叢が冬期に複 雑さを多少とも呈する理由として，冬期の気象や 生活様式といつた季節的条件が生体，ひいては菌 叢の生態に影響を及洼すからであるうと考兄てい 
る。

また，H. influenzaeはD. pneumoniaeと交互に

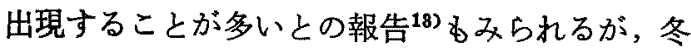
期と夏期の咽頭培養や週的变動調查での培養で同 時に出現するものも少なからずあつた。さらに， 検出率の季節的变動でる，H. influenzaeが，夏期 は冬期に比べて有意の減少を示したのにかかわら ず，D. pneumoniaeの検出率は両季節ともほぼ同 じであつた.

咽頭菌蔡の構成が堅牢であるか否かは，感染防

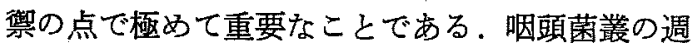
的変動の有無から菌叢の堅牢性に検討を加えてみ た．毎週同時に健康成人に実施した咽頭培養の成 績で，健康人の咽頭菌叢を構成する菌種数の週的 変化はほとんどみられず，また，咽頭培養で分離 された菌種数は，各健康人とも症注同じであつ た．さらに，咽頭菌丵を構成する菌種が固定的な ものであるか否かについての 検討で, $\alpha$-Streptococcus, Neissera, $\gamma$-Streptococcus, Micrococcus, Corynebacterium 5 菌種が 固定的菌叢で，次い で,かなり定着性の強いH. Parainfluenzae, Staph. aureusが認められることが多かつた。健康人咽頭 菌丵は，上記 5 菌種を固定的菌丵として通常 $2 \sim$ 4 種の菌が流動的に出入することが示された。よ つて，咽頭菌㦈は，ある範囲内の流動的部分之固 定的部分を有し，全体として堅牢性を維持してい ると考えられた。

抗生薬投与が咽頭菌叢の構成に及ぼす影響につ いては，従来，投与薬剤に感性を示す菌の減少と 酎性を示寸菌の增加がみられるものの，投与終了 後すみやかにもとの菌丵に回復すると考克られて きた，本研究で使用したAB-PCの場合でる，投与 後消失をみたのは感性を示す菌であり，出現した のは耐性を示す菌であつた。そして，投与終了直 後の菌叢变化は，みかけ上，すみやかに回復し た。しかし，詳細に検討を加えてみると，図1に 示したように，AB-PC投与を受けた健康人の咽頭 菌叢を構成する菌種数の週的変化は，投与終了時 にみられず，投与終了後 1 週目に菌種数の増加を
みた後，投与終了後 2 週目にもとに回復している が，投与終了後 4 週目から再度増加をきたしてい る。つまり，抗生薬投与により括こる菌叢の变化 は，一旦，又加忛の変化が回復するよらにみえ るが，その变化は少なくとも投与終了後 6 週目以 上続くと考えられた，菌種のうえでは，投与終了 後出現したStaph. epidermidisや腸内細菌と類似菌 は短期間で消失するが，週を経るごとに，Candida, Lactobacillus Haemophilusの 増加がみられ たことが特徴であつた。

呼吸器感染症で原因菌を決定することは，臨床 細菌学の分野で最も困難な問題の一つである ${ }^{13)}$. 咽頭培養から下気道の主要病原菌を想定すること むある程度可能である ${ }^{14)}$. 最近，G N Rによる肺 炎が宿主防禦能の低下した患者に増加の傾向にあ る2).こうした患者の咽頭には，数種類の G N R が見いだされることも希でない沼ため，原因菌の 決定に困惑を覚古る。この際，血中抗体価を手 慗りに原因菌の決定ができれば簡便なことであ る. 本研究では，咽頭に G NRが定着していると 考兄られる健康人について，そのGNRの生菌と 加熱菌に対する血中抗体価を測定したが，これら 抗原に対する抗体を有している健康人をみいたし 完なかつた。この事実は，咽頭に存在する G N R に関する限り，その抗体価がみい出されれば，少 なからず病因的意義を有するということであり， さらに，抗体価の推移む追求でされば，原因菌之 の決定を可能になると考えられる.

\section{結論}

金沢市在住の満15～69才の健康人 167名を対象 に，咽頭菌叢の構成について種々の観点から解析 を加えたそその成績は以下のように要約すること ができた。

1）健康成人の咽頭菌諳を棈成する菌種の範囲 と量的多寒に一定の傾向がみられた。

2）咽頭菌叢の構成は，本質的には，性別，年 令や笑煙に左右されないと考えられた。

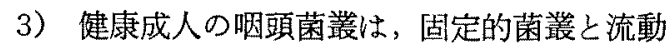
的菌莘からなりたち，全体としての堅牢性を維持 
していると考光られた。

4）冬期は，分離菌種の範囲や健康人一人あた りの分離菌種数のみならず，各菌の検出率が夏期 よりも增大する傾向を示した。

5）冬期菌叢の構成には，老令や契煙の影響な らびに菌相互の関係が複雑に作用しあつているこ とが示唆された。

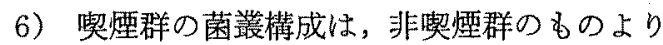
季節変化に安定なようであつた。

7）夏期菌垃は, その簡潔さから, 季節的に最 も基本的な菌趣構成を呈すると考えられた。

8）抗生薬 (ampicillin) による菌丵構成の擋 乱は，流動的菌菱に著明にあらうれ，みかけ上の 変化が回復しても，さらに引き続くことが示され た。

9）咽頭にグラム陰性桿菌を有する健康成人に は，こ机に対する血中抗体価の上昇を認めなかつ た。

稿を終えるにあたり，御指導と御校閲を睗わつた㮌 天堂大学医学部臨床病理学教室小酒井望教授飞感謝い たします。

\section{文献}

1) 小酒井望: 臨床細菌学の将来, 臨床病理, 22 : 265 268，1974，一2) 舟田 久, 服部絢一：終末 感染, 臨床之研究, $51: 3075 \sim 3083,1974 .-3)$ Rosebury, T.: Microorganisms Indigenous to
Man. McGraw-Hill, New York, 1962. -4) 䚀田

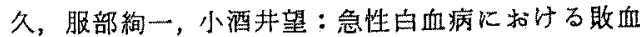
症起炎菌的棆索について，第48回日本伝染病学会総 会口演. - 5) Matsuba, K. et al.: The normal values of 15 kinds of plasma proteins of the $\mathrm{Ja}$ panese people. J. clin. Chem. 1: 70 79, 1971. 一6) 小酒井望：臨床检査技術講座，細菌学，金原 出版, 東京, 1970. -7) Cowan, S.T. and Steel, K.J.: Manual for the Identification of Medical Bacteria. Cambridge University Press, Cambridge, 1970. -8) Rogosa, M. et al.: A selective medium for the isolation and enumeration of oral and fecal Lactobacilli. J. Bact. 62: 132 133, 1951. 一9）舟田 久, 吉田 喬, 佐賀 努, 服部粅一, 浦 知恵子, 小酒井望: 急性白血病飞合併したAeromonas hydrophila 敗血症の 2 例, 日内会誌, $63: 1318$ 1329, 1974. - 10) Ribble, J.C. et al.: Bacterial interference in chick embryos. J. clin. Invest. 46 : 446 452, 1967. - 11) Young, G. et al.: Interactions of oral strains of Candida albicans and Lactobacilli. J. Bact. 72: 525 529, $1956 . \quad-12$ ) Zinnemann, K.: Haemophilus influenzae and its pathogenicity. in Ergebnisse der Mikrobiologie. Immunitätsforschung und Experimentallen Therapie, Springer-Verlag, Berlin, 1960, pp. 307 368. -13) 小酒井望 : 感染症の原因菌と険查法の問題 点, 診断と治療, $60: 708 \sim 732,1972 .-14)$ 上 原与ず子, 寺島 周, 野本泰正: 小监咽頭細菌誏 と等問題点，小児科，8:1090 1101，1967. 15) Johanson, W.G. et al.: Changing pharyngeal bacterial flora of hospitalized patients. Emergence of gram-negative bacilli. New Engl. J. Med. 281: $1137 \sim 1140,1969$. 